\title{
THE CORRELATION BETWEEN STUDENTS' MOTIVATION AND READING COMPREHENSION OF THE FIRST YEAR STUDENTS OF SMPN 1 CISARUA BANDUNG BARAT
}

\author{
Pilli Parliyah ${ }^{1}$, Tanty Khotimah ${ }^{2}$ \\ ${ }^{1}$ IKIP Siliwangi \\ ${ }^{2}$ IKIP Siliwangi \\ ${ }^{1}$ mphillyzest@gmail.com, ${ }^{2}$ Tantykhotimah127@gmail.com
}

\begin{abstract}
The objective of this study is to know the correlation between students' motivation and their achievement in reading comprehension. The research used quantitative method and correlational research as design. The population of the study was the seventh grade students of Junior High School 1 cisarua, Kabupaten Bandung Barat in academic year 2017/2018 with total number 395 students and the sample in this study is 32 students. Instruments for data collection were the questionnaire to find out students' motivation and the reading comprehension test. Pearson Product Moment was used to analyze the data and the hypothesis testing was computed by applying SPSS version 22. It was found that there is a significant correlation between students' motivation and their achievement in reading because the correlation coefficient was 0.658 . It was classified into high correlation . Thus, there is a significant correlation between reading motivation and reading motivation. The result can be interpreted that students' motivation had strong effect to reading comprehension skill. It is suggested the English teachers have to create teaching strategies that will motivate the students to read in class.
\end{abstract}

Keywords: Correlation, Students' Motivation, Reading, Achievement

\section{INTRODUCTION}

Reading is one of four competence in language and an important activity that students should be learnt. Reading is an activity to comprehend some knowledge in written language. Harmer (1998: 70) in Parmawati and Yugafiati (2017) states that, reading is an incredibly active occupation. According to (Rayner \& Reichle, 2010), Reading is a complex skill involving the orchestration of a number of components. Researchers often talk about a 'model of reading' when talking about only one aspect of the reading process (e.g., models of word identification are often referred to as 'models of reading'). Word identification related to the steps of understand how written symbols correspond to spoken language and comprehension related to the steps to comprehend the words, sentences, and connected text. In addition, (Grabe, 2009) explains reading is the skill to draw meaning from the printed page and interpret this information appropriately. (Pourhosein Gilakjani \& Sabouri, 2016) states reading is an interactive process in which readers construct a meaningful representation of a text .

From brief explanation above, it can be concluded that Reading is to process text meaning through some process of interaction with print (Alderson, 2000: 1, cited in Apsari \& Yana, 2015).When people decide to do something, they have purpose in their mind. Also when people decide to read, for sure they have a purpose as well. Even when they read novel for pleasure, at least they want to acquire knowledge about the story. Like (Bruce Arne, 1984) statement, people read because they need to reach something from the writing; whatever it was, people insisted to get the message that the writer had expressed. 
The purpose of reading is to decode information from text into one's mind (Bruce Arne, 1984). Some experts define about the purpose of reading. Generally, their definition state that reading has two main purposes: reading for entertainment and for getting information. The main purpose of reading is to reach comprehension or ability to find the meaning of what they read and answer the questions regarding to the reading text. To understand the text and mastery of reading should be done have motivation on attitudes, self-concept and experience. Since motivation does not emerge naturally but should be achieved through the steps of reading activity. The experiences, attitudes, and self-concepts, all play a significant role in motivating children to read.

Motivation is also really crusial in the step of learning especially in reading. (Wigfield, Guthrie, $\&$ McGough, 1996) say that motivation to read play an important contribution for students to achieve reading comprehensions and academic success. Students who have less motivation to get achievement in school can be said also have very low reading skill. Whether the main attention of an approach is directed at parents, teachers, students, or some other influence such as the curriculum or choice of text, there has always been a crucial area of attention for reading skill. Keller in (Made, 2009) defined motivation as intensity and direction of behavior with related to somebody's selection to do or avoid a task and to indicate the level of effort that made by him or her.

A growing body of researchers has said that motivation is the most important factor which can determine the success in foreign language learning. The statement is supported by (Westwood, 2012), motivation is significant for reading skill since it influences the choices that people make about which activity they will engage with, the level of persistence, and some efforts that they will use on a given activity. Motivation consists of two kinds, they are intrinsic and extrinsic. Intrinsic motivation (Miller, Deci, \& Ryan, 1988) refers to being motivated and curious enough to be engaged in an activity for its own sake. A comprehension goal is defined in term of a focus on learning or comprehend a task for self-improvement, development of new skills, or trying to get understanding. On the other hand, extrinsic motivation is relates to the reward an individual will get as aresult of any instrumental actions. Extrinsic motivation (Deci, Vallerand, Pelletier \& Ryan in Tercanlioglu, 2001:4) refers to efforts directed toward obtaining external recognition, rewards, or incentives. Extrinsic motivation shows the fact that children do a lot of their reading when their reading skill is given mark and compared to others' performance.

Many ways that the teachers could do to increase motivation of the students in reading. Regarding to the 2013 curriculum that is currenlty being used in Indonesia, the schools conduct the activity that is expected to increase the desire to read among students, namely the School Literacy Movement activities. Every students are supposed to read silently the storybook for 10 minutes each day at the beginning of the lesson. This activity is done to familiarize the students in reading and increase a desire to read so that in the end the national education goals will be maximally achieved. Based on those explanation above, this research would like to know the correlation between the students' motivation and reading comprehension.

\section{METHOD}

This research used a correlational research. According to Creswell (2012), correlation research is used to describe and measure the relationship between two or more variables or sets of score without controling and manipulating the variables as in an experiment. A correlation study 
(Everitt \& Minium, 2006) is to define a relationship between two variables they are; students' motivation and thier achievement in reading comprehension. The population of this study was seventh grade student of SMPN 1 Cisarua in school year 2017/2018 which consisting of 395 students. (Everitt \& Minium, 2006) says that, "Sample is a part or representative of the population that will be observed." The sample of population chosen was class 7K of SMPN 1 Cisarua that consists of 32 students .

In collecting the data, the writer give the students with the following instruments:

\section{Questionnaire}

Motivation Reading Questionnaire (MRQ) by (Wigfield et al., 1996) was used to get the data about the students' reading motivation. It is a student rated assessment of the level to which each student has motivation in reading. The original questionnaire consists of 53 items , but only 32 items of the MRQ that was used in this research. In consideration,there were some of the items have closed meaning and some of the items different with the students' culture. The questionnaire has been translated into Bahasa Indonesia in order to make it easy to be answered by the students, and can be administered in 20 to 25 minutes.

The MRQ uses likert scale with range of 1-4. It consist of very different form me, a little different from me, a little like me, a lot like me. The score of each item described as follows:

Table 1. MRQ Score for each option

\begin{tabular}{cc}
\hline Category & Score \\
\hline Very different from me & 1 \\
\hline A little different from me & 2 \\
\hline A little like me & 3 \\
\hline A lot like me & 4 \\
\hline
\end{tabular}

Source : Wigfield et, al. 1996

The questionnaire in this research arranged based on the indicator from motivation and the achievement in reading of the students.

\section{Reading Test}

The instrument materials of reading comprehension test were chosen from teacher's and students' handbook. The writer used one type of reading text, that is descriptive text. The reading test in this research had 30 questions in multiple choice form.

\section{Technique of Analysing Data}

The data from questionnaire and reading test were assessed by using Pearson Product Moment's Formula and calculated using SPSS 22.0 for windows to see the correlation. There is a correlation coefficient, which is a numerical index that give information about the strength of the relationship between both of variables. It gives information how variables are associated. The Meaning of correlation coefficient shown below

Table 2. Correlation Coefficient

\section{Interval Coefficient Level of Correlation}




\begin{tabular}{cc}
\hline $\mathbf{0 , 2 0}-\mathbf{0 , 3 5}$ & Weak \\
\hline $\mathbf{0 , 3 5}-\mathbf{0 , 6 5}$ & Fair \\
\hline $\mathbf{0 , 6 5}-\mathbf{0 , 8 5}$ & Strong \\
\hline $\mathbf{0 v e r} \mathbf{0 , 8 5}$ & Very Strong \\
\hline source: Cohen, Manion Marrison( & $2007, p$ 340)
\end{tabular}

\section{RESULTS AND DISCUSSION}

\section{Results}

\section{Result of student's reading motivation}

Students' reading motivation were identified from the questionnaire that they have already answered. A higher score indicate larger degree in reading motivation

Table 3. student's reading motivation score

\begin{tabular}{|c|c|c|}
\hline No & Name & Motivation Score \\
\hline 1 & Student 1 & 84 \\
\hline 2 & Student 2 & 102 \\
\hline 3 & Student 3 & 79 \\
\hline 4 & Student 4 & 76 \\
\hline 5 & Student 5 & 77 \\
\hline 6 & Student 6 & 110 \\
\hline 7 & Student 7 & 115 \\
\hline 8 & Student 8 & 97 \\
\hline 9 & Student 9 & 73 \\
\hline 10 & Student 10 & 81 \\
\hline & Student 11 & 106 \\
\hline 12 & Student 12 & 82 \\
\hline 13 & Student 13 & 78 \\
\hline 14 & Student 14 & 77 \\
\hline 15 & Student 15 & 77 \\
\hline 16 & Student 16 & 85 \\
\hline 17 & Student 17 & 90 \\
\hline 18 & Student 18 & 67 \\
\hline 19 & Student 19 & 107 \\
\hline 20 & Student 20 & 87 \\
\hline & Student 21 & 79 \\
\hline 22 & Student 22 & 73 \\
\hline & Student 23 & 101 \\
\hline & Student 24 & 77 \\
\hline 25 & Student 25 & 67 \\
\hline 26 & Student 26 & 93 \\
\hline
\end{tabular}

68 | The Correlation Between Students' Motivation And Reading Comprehension Of The First Year Students Of Smpn 1 Cisarua Bandung Barat 


\begin{tabular}{llr}
\hline $\mathbf{2 7}$ & Student 27 & 88 \\
\hline $\mathbf{2 8}$ & Student 28 & 108 \\
\hline $\mathbf{2 9}$ & Student 29 & 83 \\
\hline $\mathbf{3 0}$ & Student 30 & 101 \\
\hline $\mathbf{3 1}$ & Student 31 & 93 \\
\hline $\mathbf{3 2}$ & Student 32 & 102 \\
\hline
\end{tabular}

Table 4. Categories of Reading motivation

\begin{tabular}{lc}
\hline Score Interval & Categories \\
\hline $\mathbf{6 1 - 8 0}$ & Low level of motivation \\
\hline $\mathbf{8 1 - 1 0 0}$ & Medium Level of motivation \\
\hline $\mathbf{1 0 1 - 1 2 0}$ & High level of motivation \\
\hline & Source $:$ Wigfield et, al. 1996
\end{tabular}

If the students' result range of 61-80, they were considered to have low level of reading motivation, those who belong the score 81-100 it means they were medium level of reading motivation. When students' score was 101-120 it was considered to have excellent level of reading motivation.

\section{Result of Students Reading Comprehension Test}

Table 5. Reading Comprehension score

\begin{tabular}{|c|c|c|}
\hline No & Name & reading score \\
\hline 1 & Student 1 & 73 \\
\hline 2 & Student 2 & 63 \\
\hline 3 & Student 3 & 70 \\
\hline 4 & Student 4 & 33 \\
\hline 5 & Student 5 & 37 \\
\hline 6 & Student 6 & 77 \\
\hline 7 & Student 7 & 97 \\
\hline 8 & Student 8 & 63 \\
\hline 9 & Student 9 & 53 \\
\hline 10 & Student 10 & 33 \\
\hline 11 & Student 11 & 63 \\
\hline 12 & Student 12 & 30 \\
\hline 13 & Student 13 & 37 \\
\hline 14 & Student 14 & 37 \\
\hline 15 & Student 15 & 50 \\
\hline 16 & Student 16 & 60 \\
\hline 17 & Student 17 & 60 \\
\hline 18 & Student 18 & 43 \\
\hline 19 & Student 19 & 57 \\
\hline
\end{tabular}




\begin{tabular}{lll}
\hline $\mathbf{2 0}$ & Student 20 & 37 \\
\hline $\mathbf{2 1}$ & Student 21 & 43 \\
\hline $\mathbf{2 2}$ & Student 22 & 50 \\
\hline $\mathbf{2 3}$ & Student 23 & 63 \\
\hline $\mathbf{2 4}$ & Student 24 & 47 \\
\hline $\mathbf{2 5}$ & Student 25 & 47 \\
\hline $\mathbf{2 6}$ & Student 26 & 53 \\
\hline $\mathbf{2 7}$ & Student 27 & 33 \\
\hline $\mathbf{2 8}$ & Student 28 & 80 \\
\hline $\mathbf{2 9}$ & Student 29 & 33 \\
\hline $\mathbf{3 0}$ & Student 30 & 43 \\
\hline $\mathbf{3 1}$ & Student 31 & 50 \\
\hline $\mathbf{3 2}$ & Student 32 & 73 \\
\hline
\end{tabular}

Based on the students's score, the qualification were used to see whether the students has very poor, poor, average, good, and very good

Tabel 6. Range of students' reading achevement

\begin{tabular}{lll}
\hline No & Range & Qualification \\
\hline $\mathbf{1}$ & $86-100$ & Very good \\
\hline $\mathbf{2}$ & $71-85$ & Good \\
\hline $\mathbf{3}$ & $56-70$ & Average \\
\hline $\mathbf{4}$ & $41-55$ & Poor \\
\hline $\mathbf{5}$ & $0-40$ & Very poor \\
\hline
\end{tabular}

\section{Normality and linearity test}

Normality test and linearity test were conducted prior to data analysis through SPSS. Kolmogorov-Smirnov formula was applied to see the normality. The results shows the sig value for reading motivation and reading comprehension is $0.200(0,200>0,05)$. This indicated that the data from each variable were all normally distributed and appropriate for data analysis

\begin{tabular}{llrr}
\hline \multicolumn{4}{c}{ Table 7. One-Sample Kolmogorov-Smirnov Test } \\
\hline & & $\begin{array}{c}\text { Reading_Motivati } \\
\text { on }\end{array}$ & $\begin{array}{c}\text { Reading_skil } \\
\text { N }\end{array}$ \\
\hline Normal Parameters & & 32 & 32 \\
\cline { 2 - 4 } & Mean & 87,97 & 52,75 \\
\cline { 2 - 4 } & Std. & 13,345 & 16,455 \\
\hline Most Extreme & Deviation &, 124 &, 112 \\
\cline { 2 - 4 } Differences & Absolute &, 124 &, 112 \\
\cline { 2 - 4 } & Positive &,- 117 &,- 084 \\
\hline Test Statistic & Negative &, 124 &, 112 \\
\hline Asymp. Sig. (2-tailed) & & &, $200^{\text {c,d }}$ \\
\hline a. Test distribution is Normal. & & \\
\hline b. Calculated from data. & & & \\
\hline
\end{tabular}


c. Lilliefors Significance Correction.

$\mathrm{d}$. This is a lower bound of the true significance.

For linearity test, deviation of linearity was obtained. If probability score was more than 0.05 , the two or more variables were linear. It was revealed that, the deviation from linearity between reading motivation and reading comprehension skill was 0.108 . To sum up, all the data were linear for each correlation. After all of the data were found normal and linear, the analysis was done. The statistical calculation was continued. The correlation and influence among variables were analyzed.

\section{Correlation between Students' reading motivation and Reading Comprehension}

\begin{tabular}{|c|c|c|c|}
\hline \multicolumn{4}{|c|}{ Table 8. Pearson Correlations } \\
\hline & & $\begin{array}{c}\text { Motivation_S } \\
\text { core }\end{array}$ & $\underset{\text { re }}{\text { Reading_Sco }}$ \\
\hline \multirow[t]{3}{*}{$\begin{array}{l}\text { Motivation_Sco } \\
\text { re }\end{array}$} & $\begin{array}{l}\text { Pearson } \\
\text { Correlation }\end{array}$ & 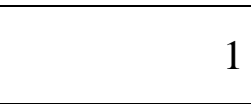 & $0,658^{* *}$ \\
\hline & Sig. (2-tailed) & & 0,000 \\
\hline & $\mathrm{N}$ & 32 & 32 \\
\hline \multirow[t]{3}{*}{ Reading_Score } & $\begin{array}{l}\text { Pearson } \\
\text { Correlation }\end{array}$ & $0,658^{* *}$ & 1 \\
\hline & Sig. (2-tailed) & 0,000 & \\
\hline & $\mathrm{N}$ & 32 & 32 \\
\hline
\end{tabular}

**. Correlation is significant at the 0.01 level (2-tailed).

\section{Discussion}

Based on Pearson Product Moment Correlation calculation through SPSS 22, the result showed $\mathrm{p}$ is 0.000 , it can be said that the result is significant because $\mathrm{p}<0.05$. The coefficient correlation between students' motivation and their reading comprehension is 0.658 . Based on the the classification of the correlation coefficient, it can be categorized as high correlation. Therefore, null hypothesis (Ho) was rejected and research hypothesis (H1) was accepted. It can be concluded that there was correlation between students' motivation and their reading comprehension achievement.

\section{CONCLUSION}

From the results of this study, the obtained value of correlation coefficient is 0.658 which imply that there is a high correlation between reading motivation and reading comprehension. The witer concludes that motivation influences students'reading comprehension achivement and students who have have higher motivation tend to have better reading achievement. Therefore, the researchers would like to suggest the students to maintain their motivation about reading so it will give positive contribution on their comprehension. Not only for students, the researcher also would like to propose that the English teacher suppose to motivate their students about the urgency of reading. The teacher should take some efforts to develop student's motivation and encourage the to practice in reading comprehension. 


\section{ACKNOWLEDGMENTS}

We would like to thank the principal, teachers, and all of the students from the seventh grade SMPN 1 Cisarua Bandung Barat, for their gracious help in admitting the research. We would also like to thanks to one of the lecturer of English Education Departement at IKIP Siliwangi Bandung who has given her suggestions and critics.

\section{REFERENCES}

Apsari, Y., \& Yana, Y. (2015). Teachers'techniques And Problems In Teaching Reading. P2m Stkip Siliwangi, 2(2), 217-233.

Bruce Arne, S. (1984). Teaching Reading Skills In A Foreign Language. Nuttall, Christine, London: Heinemann Educational Books, 1982, Xi+233 Pp, (Practical Language Teaching No.9). System. Https://Doi.Org/10.1016/0346-251x(84)90031-9

Creswell, J. W. (2012). Educational Research: Planning, Conducting, And Evaluating Quantitative And Qualitative Research. Educational Research. Https://Doi.Org/10.1017/Cbo9781107415324.004

Everitt, B. S., \& Minium, E. W. (2006). Statistical Reasoning In Psychology And Education. Journal Of The Royal Statistical Society. Series A (General). Https://Doi.Org/10.2307/2343670

Grabe, W. (2009). Reading In A Second Language Moving From Theory To Practice. Reading In A Second Language: Moving From Theory To Practice.

Made, W. (2009). Strategi Pembelajaran Inovatif Kontemporer: Suatu Tinjauan Konseptual Operasional. Jakarta: Pt. Bumi Aksara.

Miller, K. A., Deci, E. L., \& Ryan, R. M. (1988). Intrinsic Motivation And Self-Determination In Human Behavior. Contemporary Sociology. Https://Doi.Org/10.2307/2070638

Parmawati, A., \& Yugafiati, R. (2017). Using Authentic Material To Improve Students'reading Interest (A Classroom Action Research In The Second Semester Students Of Stkip Siliwangi Bandung). Eltin Journal, Journal Of English Language Teaching In Indonesia, $5(1), 1-8$.

Pourhosein Gilakjani, A., \& Sabouri, N. B. (2016). How Can Students Improve Their Reading Comprehension Skill? Journal of Studies In Education. Https://Doi.Org/10.5296/Jse.V6i2.9201

Rayner, K., \& Reichle, E. D. (2010). Models Of The Reading Process. Wiley Interdisciplinary Reviews: Cognitive Science. Https://Doi.Org/10.1002/Wcs.68

Westwood, P. (2012). Reading Comprehension: Assisting Children With Learning Difficulties. Australian Journal Of Learning Difficulties. Https://Doi.Org/10.1080/19404158.2011.650650

Wigfield, A., Guthrie, J. T., \& Mcgough, K. (1996). A Questionnaire Measure Of Children's Motivations For Reading (Instructional Resource No. 22). Instructional Resource. 